\title{
IMPLEMENTASI MODEL PEMBELAJARAN DEEP DIALOGUE/CRITICAL THINKING (DD/CT) UNTUK MENINGKATKAN KEMAMPUAN BERPIKIR KRITIS DAN MINAT BELAJAR SISWA PADA PEMBELAJARAN PKN POKOK BAHASAN BUDAYA POLITIK DI INDONESIA PADA SISWA KELAS XI IPA 3 SMA NEGERI 1 SELESAI KABUPATEN LANGKAT SEMESTER GENAP TAHUN PELAJARAN 2018/2019
}

\author{
Drs.AMARUDDIN \\ SMA Negeri 1 Selesai \\ Jl.Binjai Selayang Simp.Selesai Kec.Selesai
}

\begin{abstract}
ABSTRAK
Penelitian ini bertujuan untuk mengetahui bagaimana upaya meningkatkan kemampuan berpikir kritis dan minat belajar siswa dengan menerapkan model pembelajaran Deep Dialogue/Critical Thinking (DD/CT) di Kelas XI IPA 3 SMA Negeri 1 Selesai Kabupaten Langkat. Penelitian ini juga bertujuan untuk mengetahui peningkatan minat belajar dan kemampuan berpikir kritis siswa dengan menggunakan model pembelajaran Deep Dialogue/Critical Thinking (DD/CT) di kelas XI IPA 3 SMA Negeri 1 Selesai. Jenis penelitian ini adalah Penelitian Tindakan Kelas (Classroom Action Research) yang mencakup perencanaan, tindakan dan pengamatan, serta refleksi. Subjek penelitian ini adalah siswa kelas XI IPA 3 SMA Negeri 1 Selesai Kabupaten Langkat Semester Genap Tahun Pelajaran 2018/2019. Teknik pengumpulan data terdiri dari observasi, catatan lapangan, wawancanra dan dokumentasi. Keabsahan data dapat diketahui melalui triangulasi teknik. Teknik analisis data yang digunakan yaitu analisis kualitatif model Miles dan Huberman mencakup reduksi data, penyajian data, dan penarikan kesimpulan/verifikasi.

Upaya meningkatkan minat belajar dan kemampuan berpikir kritis siswa pada pembelajaran PKn di kelas XI IPA 3 SMA Negeri 1 Selesai dapat dilakukan menggunakan model pembelajaran Deep Dialogue/Critical Thinking disertai dengan lembar kerja bergambar dan pemberian motivasi berupa penghargaan. Peningkatan minat belajar dan kemampuan berpikir kritis siswa dapat ditunjukkan dengan perolehan rerata persentase minat belajar siswa siklus I 72,07\% meningkat pada siklus II sebesar 92,67\% dengan gain percentage sebesar $0,73 \%$ (kategori tinggi) dan perolehan rerata persentase kemampuan berpikir kritis siswa pada siklus I sebesar 71,74\% meningkat pada siklus II sebesar 92,12\% dengan gain percentage sebesar $0,72 \%$ (kategori tinggi). Peningkatan dari siklus I ke siklus II tersebut sudah mencapai $\geq 75 \%$ atau kriteria keberhasilan yang ditentukan, sehingga penelitian ini dikatakan berhasil.
\end{abstract}

Kata kunci : Implementasi, Berpikir Kritis, Deep Dialogue/Critical Thinking. 


\section{PENDAHULUAN}

Kualitas pendidikan merupakan aspek terpenting dalam usaha pembangunan yang sedang dilaksanakan di Indonesia. Hal ini sangat erat hubungannya dengan tujuan pembangunan masyarakat Indonesia seutuhnya. Melalui pendidikan diharapkan harkat dan martabat masyarakat Indonesia dapat ditingkatkan, baik di kalangan nasional maupun internasional. Pendidikan yang berkualitas dapat diwujudkan melalui proses pembelajaran di sekolah. Proses pembelajaran di sekolah menempatkan guru dan siswa sebagai komponen vital, karena keduanya saling terkait satu sama lain dengan tugas dan peranan yang berbeda. Pada kegiatan pembelajaran, diperlukan kemampuan berpikir kritis untuk dimiliki siswa. Kemampuan berpikir kritis sangat diperlukan dalam kehidupan karena pada abad 21 kemampuan berpikir kritis merupakan era informasi dan teknologi. Siswa harus merespons perubahan dengan cepat dan efektif, sehingga memerlukan keterampilan intelektual yang fleksibel, kemampuan menganalisis informasi, dan mengintegrasikan berbagai sumber pengetahuan untuk memecahkan masalah. Oleh karena itu, melalui kemampuan berpikir kritis, siswa yang memiliki kemampuan berpikir kritis tentu tidak terbentuk dengan sendirinya. Diperlukan minat atau keinginan yang muncul dalam dirinya untuk diharapkan mampu menganalisis sesuatu yang berguna atau tidak

berguna bagi dirinya, keluarga, masyarakat dan bangsanya di masa depan. mengikuti dan memahami kegiatan pembelajaran secara lebih mendalam. Ketika siswa memiliki minat dalam dirinya untuk belajar suatu hal, maka ia akan memikirkan hal tersebut secara mendalam dan menggabungkan ide-ide yang muncul dari dalam dirinya untuk memecahkan masalah dalam pembelajaran tersebut. Jadi, untuk menumbuhkan minat dan kemampuan siswa berpikir kritis ini tidak terlepas dari pemilihan model pembelajaran oleh guru. Diperlukan model pembelajaran yang dapat menumbuhkan minat belajar dan kemampuan berpikir kritis siswa

Pemilihan model pembelajaran yang sesuai dengan potensi siswa dan tujuan kurikulum merupakan kemampuan dan keterampilan dasar yang harus dimiliki oleh seorang guru (Oemar Hamalik, 2011: 201). Ketepatan guru dalam memilih model pembelajaran akan berpengaruh terhadap keberhasilan pembelajaran. Dalam konteks ini pembelajaran berpusat pada siswa, proses belajar mengajar didasarkan kebutuhan dan minat siswa. Model pembelajaran seperti ini dirancang untuk menyediakan sistem belajar yang fleksibel sesuai dengan kehidupan dan gaya belajar siswa. Pada kenyataanya, tidak semua guru mampu menguasai model-model pembelajaran yang sesuai dengan tujuan kurikulum dan potensi siswa, seperti yang terjadi di SMA Negeri 1 Selesai Kabupaten Langkat.

Guru jarang menggunakan model pembelajaran yang melibatkan siswa secara aktif. Kegiatan pembelajaran terlalu terpusat pada guru, hal ini terlihat pada saat peneliti melaksanakan observasi pra tindakan pada tanggal 20 November 2017 ketika kegiatan pembelajaran berlangsung guru hanya menyampaikan materi secara ceramah tanpa melibatkan siswa untuk berpendapat dan terlibat aktif. Selain dari faktor guru, kendala lain yang terjadi dalam pembelajaran di sekolah adalah rendahnya kemampuan berpikir kritis dan minat siswa dalam mengikuti pelajaran. Seperti halnya pelajaran PKn, banyak siswa menganggap bahwa mata pelajaran PKn adalah mata pelajaran yang penuh dengan hapalan dan membosankan. Kecenderungan ini menyebabkan rendahnya 
minat siswa terhadap pembelajaran PKn. Siswa menjadi pasif, bahkan siswa lebih sering bergurau dan gaduh di dalam kelas. Berdasarkan uraian di atas, maka peneliti tertarik untuk meningkatkan kemampuan berpikir kritis dan minat belajar PKn salah satunya dengan menggunakan model pembelajaran deep dialoguel critical thinking. Model pembelajaran deep dialogue/ critical thinking adalah suatu model pembelajaran yang tepat untuk diterapkan pada mata pelajaran PKn karena jika dilihat dari kelebihan model pembelajaran ini, melalui kegiatan berdialog/berdiskusi secara mendalam untuk memecahkan masalah ataupun tugas dari guru yang diberikan, siswa dapat melatih kemampuan berpikir kritis mereka.

\section{METODOLOGI PENELITIAN}

Penelitian ini dilaksanakan di kelas XI IPA 3 SMA Negeri 1 Selesai Kabupaten Langkat Semester Genap Tahun Pelajaran 2018/2019 dengan lama penelitian 3 Bulan (Januari sampai dengan Maret 2019). Penelitian ini termasuk dalam Penelitian Tindakan Kelas (Action Research). Penelitian ini dilaksanakan untuk meningkatkan minat dan kemampuan berpikir siswa dalam pembelajaran PKn menggunakan model pembelajaran Deep Dialogue/Critical Thinking. Dalam penelitian tindakan kelas ini melaksanakan empat aspek penting yaitu perencanaan, tindakan dan observasi, refleksi.

Instrumen penelitian utama adalah peneliti, artinya, peneliti dalam penelitian ini berperan sebagai perencana, pelaksana, pengumpul data, penganalisis, penafsir data, dan pada akhirnya menjadi pelapor hasil penelitiannya (Moleong, 2002: 121). Instrumen yang digunakan untuk mengukur kemampuan berpikir kritis dan minat belajar siswa adalah dengan menggunakan angket. Pada penelitian ini, peneliti bertugas dalam proses perencanaan, pengamatan, dan refleksi.

Dalam penelitian ini bentuk analisis data menggunakan analisis kualitatif. Data yang berhasil dikumpulkan melalui teknik observasi, wawancara, catatan lapangan dan dokumentasi kemudian dianalisis mengacu pada metode analisis dari Miles \& Huberman (Sugiyono, 2011: 334-343), metode analisis tersebut terdiri dari tiga komponen yaitu reduksi data, sajian data dan penarikan kesimpulan. Tindakan Untuk mengukur keberhasilan tindakan dalam penelitian ini adalah penelitian ini dikatakan berhasil apabila rata-rata presentase tiap indikator minat belajar siswa mencapai $75 \%$. Penelitian ini dikatakan berhasil apabila rata-rata presentase tiap indikator kemampuan berpikir kritis peserta didik mencapai $75 \%$.

\section{HASIL DAN PEMBAHASAN Hasil Pelaksanaan Tindakan Siklus I}

Penelitian tindakan kelas dilaksanakan dalan dua siklus yang setiap siklusnya terdiri dari dua pertemuan dan setiap pertemuan berlangsung selama 2 x 40 menit. Penelitian ini dilaksanakan pada tanggal 22 Januari 2019 sampai dengan tanggal 29 Januari 2019 pukul 11.00-12.20 WIB.

a. Perencanaan

Tahap-tahap perencanaan tindakan yang dilakukan pada penelitian siklus I meliputi persiapan RPP, materi pembelajaran dan 5 soal subyektif, lembar observasi minat, lembar observasi berpikir kritis, lembar observasi pelaksanaan pembelajaran PKn menggunakan model pembelajaran Deep Dialogue/Critical Thinking, pedoman wawancara.

b. Tindakan

Pertemuan 1 dilaksanakan pada hari Selasa 22 Januari 2019 pukul 11.00-12.20 dan 
pertemuan 2 dilaksanakan pada hari Kamis 22 Januari 2019 pukul 11.00-12.20 WIB.

\section{c. Pengamatan/Observasi}

1) Pengamatan Terhadap Pelaksanaan penggunaan Model Pembelajaran Deep Dialogue/Critical Thinking dalam Pembelajaran PKn.

Berdasarkan hasil observasi pelaksanaan model pembelajaran deep dialogue/critical thinking pada siklus I menunjukkan bahwa 14 dari 17 aspek telah terlaksana dengan baik.

2) Pengamatan Minat Belajar Siswa

Berikut ini adalah tabel pengamatan minat siswa pada siklus I berdasarkan hasil observasi:

Tabel 1. Data Minat Belajar Siswa Kelas XI IPA 3 Siklus I

\begin{tabular}{llcccc}
\hline \multirow{2}{*}{ No } & \multirow{2}{*}{ Aspek Minat } & \multicolumn{3}{c}{ Skor Minat Siklus I } & Persentase \\
\cline { 2 - 5 } & Per 1 & Per 2 & Rerata & $\%$ \\
\hline 1. & $\begin{array}{l}\text { Tertarik dengan } \\
\text { pelajaran PKn. }\end{array}$ & 2,68 & 3,09 & 2,89 & 72,26 \\
\hline 2. & $\begin{array}{l}\text { Keinginan untuk } \\
\text { belajar. }\end{array}$ & 2,81 & 3 & 2,90 & 72,65 \\
\hline 3. & $\begin{array}{l}\text { Perhatian yang } \\
\text { besar } \\
\text { pada hal yang } \\
\text { dipelajari. }\end{array}$ & 2,50 & 2,96 & 2,73 & 68,35 \\
\hline 4. & & & & \\
& $\begin{array}{l}\text { Partisipasi dan } \\
\text { keaktifan dalam }\end{array}$ & 3 & 3 & 3 & 75 \\
$\quad$ KBM & & & & \\
\hline Jumlah Total & 11 & 12,0 & 11,53 & 288,2 \\
& & 6 & & 8 \\
\hline Rata -rata & 2,75 & 3,01 & 2,88 & 72,07 \\
\hline
\end{tabular}

3) Pengamatan Kemampuan Berpikir Kritis Siswa

Berikut ini adalah tabel hasil observasi kemampuan berpikir kritis siswa pada siklus I:

Tabel 2 . Data Kemampuan Berpikir Kritis Siswa Kelas XI IPA 3 Siklus I

\begin{tabular}{|c|c|c|c|c|c|}
\hline \multirow[t]{2}{*}{ No } & \multirow{2}{*}{$\begin{array}{l}\text { Aspek } \\
\text { Kemampuan } \\
\text { Berpikir Kritis }\end{array}$} & \multicolumn{3}{|c|}{$\begin{array}{c}\text { Skor Kemampuan } \\
\text { Berpikir Kritis }\end{array}$} & \multirow{2}{*}{$\begin{array}{c}\text { Persentase } \\
\%\end{array}$} \\
\hline & & Per 1 & Per 2 & Rerata & \\
\hline 1. & $\begin{array}{l}\text { Mampu } \\
\text { berkomunikasi } \\
\text { dengan orang lain. }\end{array}$ & 2,75 & 3,09 & 2,92 & 73,04 \\
\hline 2. & Mampu & 2,46 & 3,12 & 2,79 & 69,92 \\
\hline
\end{tabular}

\begin{tabular}{|c|c|c|c|c|c|}
\hline & $\begin{array}{l}\text { menjelaskan } \\
\text { masalah }\end{array}$ & & & & \\
\hline 3. & $\begin{array}{l}\text { Mampu mengolah } \\
\text { informasi dalam } \\
\text { proses diskusi }\end{array}$ & 2,5 & 3,09 & 2,79 & 69,92 \\
\hline 4. & $\begin{array}{l}\text { Mampu } \\
\text { mengemukakan } \\
\text { pendapat }\end{array}$ & 3 & 3,46 & 3,23 & 80,85 \\
\hline 5. & $\begin{array}{l}\text { Mampu memberi } \\
\text { solusi atas sebuah } \\
\text { masalah }\end{array}$ & 2,65 & 3 & 2,82 & 70,70 \\
\hline 6. & $\begin{array}{l}\text { Mampu menarik } \\
\text { kesimpulan }\end{array}$ & 2,40 & 2,87 & 2,64 & 66,01 \\
\hline \multicolumn{2}{|c|}{ Jumlah Total } & $\begin{array}{c}15,7 \\
8 \\
\end{array}$ & $\begin{array}{c}18,6 \\
6 \\
\end{array}$ & 17,21 & 430,46 \\
\hline \multicolumn{2}{|c|}{ Rerata } & 2,63 & 3,10 & 2,86 & 71,74 \\
\hline
\end{tabular}

\section{d. Refleksi}

Berdasarkan observasi yang dilakukan pada siklus I menunjukkan bahwa selama pelaksanaan pembelajaran $\mathrm{PKn}$ dengan menggunakan model pembelajaran Deep Dialogue/Critical Thinking masih belum optimal dan terdapat kekurangan.

Adapun hambatan yang terjadi pada saat pembelajaran yaitu:

1) Ketertarikan siswa pada pembelajaran PKn masih rendah.

2) Keinginan siswa untuk mempelajari $P K n$ secara mendalam juga rendah.

3) Minat belajar siswa yang juga ditunjukkan dengan perhatian terhadap hal yang dipelajari tergolong rendah.

4) Kemampuan siswa untuk menjelaskan masalah masih rendah.

5) Kemampuan untuk membeikan solusi atas sebuah masalah dan kesimpulan juga rendah.

Kekurangan atau hambatan tersebut haruslah di atasi dengan cara antara lain sebagai berikut:

1) Guru perlu mengatur dalam pembagian kelompok siswa.

2) Guru perlu mengkondisikan siswa.

3) Guru perlu memotivasi siswa agar lebih berminat pada kegiatan pembelajaran PKn. 
4) Guru perlu memperbaiki lembar kerja siswa, agar siswa tidak kebingungan dalam menjawab pertanyaan yang diberikan guru.

5) Guru perlu membiasakan siswa untuk berpendapat sdalam diskusi. Guru juga perlu membantu siswa untuk menarik kesimpulan.

\section{Hasil Pelaksanaan Tindakan Siklus II}

Siklus II dilaksanakan sebagai perbaikan dari pelaksanaan tindakan dengan menerapkan model pembelajaran Deep Dialogue/Critical Thinking pada siklus I.

a. Perencanaan

Perencanaan siklus II dilakukan dengan tujuan merencanakan tindakan yang akan dilaksanakan sebagai perbaikan berdasarkan refleksi dan kekurangan yang ada pada siklus sebelumnya.

b. Tindakan

Pertemuan 1 dilaksanakan pada hari Selasa 12 Februari 2019 pukul 11.0012.20. Pertemuan 2 dilaksanakan pada hari Kamis 19 Februari 2019 pukul 11.0012.20 WIB.

c. Observasi

Observasi pada siklus II dilaksanakan pada saat kegiatan pembelajaran berlangsung. Obsevasi dilaksanakan untuk mengamati pelaksanaan penggunaan model pembelajaran Deep Dialogue/Critical Thinking dalam pembelajaran, minat belajar dan kemampuan berpikir kritis siswa dalam kegiatan pembelajaran PKn.

Berdasarkan hasil observasi terhadap pelaksanaan pembelajaran PKn menggunakan model pembelajaran Deep Dialogue/Critical Thinking pada siklus II menunjukkan bahwa 17 dari 17 aspek keterlaksanaan pembelajaran telah dilaksanakan dengan baik. Persentase keterlaksanaan pembelajaran PKn dengan menggunakan model pembelajaran Deep Dialogue/Critical Thinking pada siklus II mencapai $100 \%$. a. Pengamatan terhadap minat belajar siswa

Berdasarkan hasil observasi minat belajar siswa pada siklus II maka diperoleh hasil sebagai berikut:

Tabel 3.Data Minat Belajar Siswa Kelas XI IPA 3 Siklus II

\begin{tabular}{llcccc}
\hline \multirow{2}{*}{ No } & Aspek Minat & \multicolumn{3}{c}{ Skor Minat Siklus I } & Persentase \\
\cline { 3 - 4 } & Per 1 & Per 2 & Rerata & \% \\
\hline 1. & $\begin{array}{l}\text { Tertarik dengan } \\
\text { pelajaran PKn. }\end{array}$ & 3,68 & 3,78 & 3,73 & 93,35 \\
\hline $\begin{array}{l}\text { 2. } \\
\text { Keinginan untuk } \\
\text { belajar. }\end{array}$ & 3,56 & 3,78 & 3,67 & 91,79 \\
\hline 3. & $\begin{array}{l}\text { Perhatian yang } \\
\text { besar } \\
\text { pada hal yang } \\
\text { dipelajari. }\end{array}$ & 3,65 & 3,81 & 3,73 & 93,35 \\
\hline 4. & $\begin{array}{l}\text { Partisipasi dan } \\
\text { keaktifan dalam } \\
\text { KBM }\end{array}$ & 3,68 & 3,68 & 3,68 & 92,18 \\
\hline Jumlah Total & 14,5 & 15,0 & 14,82 & 370,70 \\
& 9 & 6 & & \\
\hline Rerata & 3,64 & 3,76 & 3,71 & 92,67 \\
\hline
\end{tabular}

b. Pengamatan terhadap berpikir kritis siswa berdasarkan hasil observasi kemampuan berpikir kritis siswa pada siklus II maka diperoleh hasil sebagai berikut:

Tabel 4. Data Kemampuan Berpikir Kritis Siswa Kelas XI IPA 3 Siklus II

\begin{tabular}{|c|c|c|c|c|c|}
\hline \multirow{2}{*}{ No } & \multirow{2}{*}{ Aspek Minat } & \multicolumn{3}{|c|}{ Skor Minat Siklus I } & \multirow{2}{*}{$\begin{array}{c}\text { Persentase } \\
\%\end{array}$} \\
\hline & & Per 1 & Per 2 & Rerata & \\
\hline 1. & $\begin{array}{l}\text { Mampu } \\
\text { berkomunikasi } \\
\text { dengan orang lain. }\end{array}$ & 3,40 & 3,71 & 3,56 & 89,06 \\
\hline 2. & $\begin{array}{l}\text { Mampu menjelaskan } \\
\text { Masalah }\end{array}$ & 3,40 & 3,78 & 3,59 & 89,84 \\
\hline 3. & $\begin{array}{l}\text { Mampu mengolah } \\
\text { informasi dalam } \\
\text { proses diskusi }\end{array}$ & 3,75 & 3,90 & 3,82 & 95,70 \\
\hline 4. & $\begin{array}{l}\text { Mampu } \\
\text { mengemukakan } \\
\text { pendapat }\end{array}$ & 3,59 & 3,90 & 3,75 & 93,75 \\
\hline 5. & $\begin{array}{l}\text { Mampu memberi } \\
\text { solusi atas sebuah } \\
\text { masalah }\end{array}$ & 3,53 & 3,87 & 3,70 & 92,57 \\
\hline 6. & $\begin{array}{l}\text { Mampu menarik } \\
\text { kesimpulan }\end{array}$ & 3,65 & 3,68 & 3,67 & 91,79 \\
\hline \multirow{2}{*}{\multicolumn{2}{|c|}{ Jumlah Total }} & 21,3 & 22,87 & 22,10 & 552,7 \\
\hline & & 4 & & & 3 \\
\hline \multicolumn{2}{|c|}{ Rerata } & 3,55 & 3,81 & 3,68 & 92,12 \\
\hline
\end{tabular}


d.Refleksi

Pelaksanaan pembelajaran PKn menggunakan model pembelajaran Deep Dialogue/Critical Thinking pada siklus II telah mempu meningkatkan minat dan kemampuan berpikir kritis siswa. Hal ini dikarenakan seluruh aspek minat dan kemampuan berpikir kritis telah mencapai kriterian keberhasilan tindakan yakni $\geq 75 \%$.

Semua aspek kemampuan berpikir kritis siswa juga mengalami peningkatan. Siswa mampu berkomunikasi dengan orang lain. Dalam kegiatan diskusi siswa mendiskusikan tugas untuk dikerjakan dengan temannya baik dalam kelompok besar maupun kecil. Siswa mampu menjelaskan masalah yang diberikan. Kemampuan mengolah informasi dalam proses diskusi juga meningkat. Siswa memanfaatkan berbagai sumber informasi baik dari buku teks maupun penjelasan dari guru untuk diolah dan dirangkum menjadi jawaban yang tepat. Pada saat kegiatan diskusi siswa aktif dalam berpendapat dan memberikan solusi atas sebuah masalah yang ada. Siswa juga mengalami peningkatan kemampuan menyimpulkan suatu masalah.

Peningkatan setiap minat belajar dan kemampuan berpikir kritis siswa dalam pembelajaran PKn sudah mencapai kriteria keberhasilan tindakan yakni $\geq 75 \%$. Rerata persentase minat belajar siswa pada siklus II telah mencapai 92,67\%. Rerata kemampuan berpikir kritis siswa pada siklus II telah mencapai 92,16\%. Bedasarkan hasil tersebut maka penelitian ini dihentikan pada siklus II.

\section{Pembahasan}

\section{Peningkatan Keterlaksanaan Model Pembelajaran Deep Dialogue/Critical Thinking.}

Model pembelajaran Deep

Dialogue/Critical Thinking merupakan model pembelajaran kooperatif yang mampu mengaktifkan siswa. Adapun secara garis besar langkah-langkah kegiatannya yaitu, a) Guru membuka pembelajaran; b) Guru menyampaikan apersepsi; c) Guru menyampaikan tujuan pembelajaran; d) Guru menjelaskan materi baru secara singkat; e) Guru membagi kelompok kecil danmemberi masalah/ tugas pada kelompok kecil untuk berdialog dan berpikir kritis; f) Memberikan pertanyaan secara acak kepada kelompok kecil; g) Guru membentuk siswa dalam kelompok besar untuk mendiskusikan kembali tugas yang diberikan h) Siswa mempresentasikan hasil diskusi mereka dan diberikan waktu untuk tanya-jawab; i) Guru melakukan refleksi bersama siswa dan memberikan point penting dari materi materi yang telah disampaikan.

Berdasarkan observasi terhadap keterlaksanaan penerapan model pembelajaran Deep Dialogue/Critical Thinking pada siklus I mencapai $85,29 \%$. Pada pelaksanaan tersebut, masih terdapat langkah-langkah pembelajaran yang tidak terlaksana. Adapun kekurangan pada siklus I meliputi: poin penting dari materi yang disampaikan belum diberikan oleh guru, guru dan siswa belum menyimpulkan kegiatan pembelajaran bersama-sama, tugas untuk pertemuan selanjutnya belum disampaikan oleh guru dan guru belum sempat menutup kegiatan pembelajaran. Kekurangan tersebut diperbaiki pada siklus II. Hasil observasi menunjukkan persentase keterlaksanaan model pembelajaran Deep Dialogue/Critical Thinking meningkat menjadi $100 \%$. Hal tersebut dikarenakan adanya perbaikan perencanaan siklus 2 berdasarkan refleksi siklus 1. Perbaikan tersebut antara lain guru menjelaskan secara rinci mengenai kegiatan pembelajaran dengan menggunakan model pembelajaran Deep Dialogue/Critical Thinking, guru lebih mengkondisikan siswa agar siswa tidak gaduh dan membuat kegiatan pembelajaran menjadi terhambat dan guru lebih mengoptimalkan 
waktu diskusi bagi siswa agar kegiatan pembelajaran berjalan lancar.

\section{Peningkatan Minat Belajar Siswa dengan Menggunakan Model Pembelajaran Deep Dialogue/Critical Thinking.}

Hasil peningkatan minat disajikan dalam histogram pada Gambar 1 yaitu sebagai berikut:

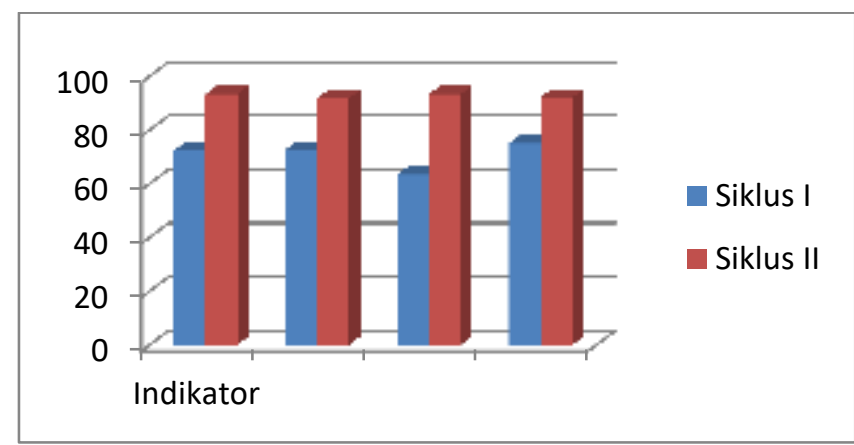

Gambar1. Histogram Peningkatan Minat Belajar Siswa Kelas XI IPA 3 Menggunakan Model Pembelajaran Deep Dialogue/Critical Thinking

Berdasarkan Gambar 1 diatas menunjukkan bahwa terdapat peningkatan minat dari sikus I ke II yaitu sebesar 0,73\%. Gain percentage tersebut masuk dalam kategori tinggi. Rerata pada siklus I belum mencapai indikator keberhasilan karena kurang dari angka $75 \%$ yakni $72,07 \%$. Rerata persentase minat pada siklus II sudah mencapai indikator yakni mencapai angka 92,18\%. Hal ini menunjukkan bahwa penggunaan model pembelajaran Deep 1 . Dialogue/Critical Thinking mampu meningkatkan minat belajar siswa terbukti dengan persentase minat siswa yang melebihi kriteria keberhasilan tindakan.

\section{Peningkatan Kemampuan Berpikir Kritis Menggunakan Model Pembelajaran Deep Dialogue/Critical Thinking.}

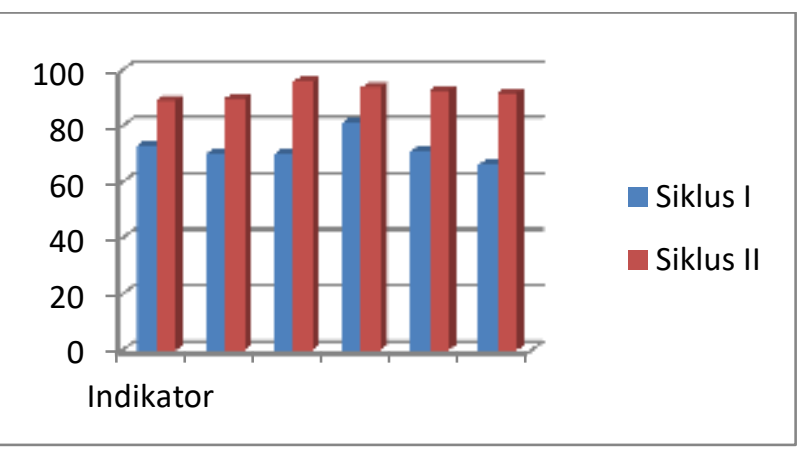

Gambar 2. Histogram Peningkatan Kemampuan Berpikir Kritis Siswa Kelas XI IPA 3 Menggunakan Model Pembelajaran Deep Dialogue/Critical Thinking

Berdasarkan Gambar 2 menunjukkan bahwa terdapat peningkatan kemampuan berpikir kritis siswa dari sikus I ke II yaitu sebesar $0,72 \%$. Gain percentage tersebut masuk dalam kategori tinggi. Rerata pada siklus I belum mencapai indikator keberhasilan karena kurang dari angka 75\% yakni 71,74\%. Rerata persentase minat pada siklus II sudah mencapai indikator yakni mencapai angka 92,12\%. Hal ini menunjukkan bahwa penggunaan model pembelajaran Deep Dialogue/Critical Thinking mampu meningkatkan kemampuan berpikir kritis siswa.

\section{KESIMPULAN}

Berdasarkan hasil penelitian dan pembahasan, maka dapat disimpulkan bahwa:

. Upaya peningkatan kemampuan berpikir kritis dan minat belajar siswa dengan model pembelajaran Deep Dialogue/Critical Thinking pada mata pelajaran PKn di kelas XI IPA 3 SMA Negeri 1 Selesai Semester Ganjil Tahun Pelajaran 2018/2019 dapat dilakukan dengan melibatkan siswa untuk berdialog secara mendalam bersama kelompok kecil yang terdiri dari 2 anak dan dilanjutkan dengan diskusi dalam kelompok besar yang terdiri dai 4 anak. Penerapan model pembelajaran Deep Dialogue/Critical Thinking tersebut dengan disertai pemberian lembar kerja siswa bergambar serta pemberian motivasi bagi siswa 
dalam kegiatan pembelajaran lebih memacu siswa untuk berpikir kritis dan meningkatkan minat siswa.

2. Penggunaan model pembelajaran Deep Dialogue/Critical Thinking dapat meningkatkan kemampuan berpikir kritis dan minat belajar siswa kelas XI IPA 3 SMA Negeri 1 Selesai . Hal ini ditunjukkan dengan peningkatan setiap indikator kemampuan berpikir kritis dan minat belajar siswa dalam pembelajaran PKn dari hasil observasi, wawancara dan catatan lapangan.

\section{DAFTAR PUSTAKA}

Abdul Wahid. (1998). Menumbuhkan Bakat dan Minat Anak. Yogyakarta: Pustaka Pelajar.

Achmad Sugandi. (2004). Teori Pembelajaran. Semarang: UPT MKK UNNES

Agus Suprijono. (2010). Cooperative Learning. Yogyakarta: Pustaka Pelajar

Anita Lie. (2007). Cooperative Learning. Jakarta: Gramedia Widiasarana Indonesia.

Bowell \& Kemp.(2002). Critical Thinking: A Concis Guide. London: Roudledge

Cece Wijaya. (1995). Pendidikan Remedial Sarana Pengembangan Sumber Daya Manusia. Bandung: Remaja Rosdakarya

Dalyono. (2007). Psikologi Pendidikan. Jakarta: Rineka Cipta

Daryanto. (2001). Evaluasi Pendidikan. Jakarta: Rineka Cipta

Etin Solihatin dan Raharjo.(2009). Cooperative Learning Analisis Model Pembelajaran IPS. Jakarta: Bumi Aksara

Jhonson, Elaine B. (2011). Contextual Teaching and Learning: Menjadikan
KBM Mengasyikkan dan Bermakna. Penerjemah Ibnu Setiawan. Bandung: Kaita

Kemmis, Stephen \& Mc Taggart, Robin. (1988). The Action Research Planner. Third edition. Victoria: Deaken University

Lexy J. Moloeng.(2004). Metodologi Penelitian Kualitatif. Bandung: Remaja Rosdakarya

Miftahul Huda. (2011). Cooperative Learning. Semarang: Pustaka Pelajar

Muhibin Syah. (2010). Psikologi Belajar. Jakarta: Raja Grafindo Persada

Mustaqim.(2008). Psikologi Pendidikan. Semarang: Pustaka Pelajar

Nasution. (2011). Berbagai Pendekatan dalam Proses Belajar Mengajar. Jakarta:

PT. Bumi Aksara Ngalim Purwanto. (2010). Prinsip-Prinsip dan Teknik Evaluasi Pengajaran. Bandung: Remaja

Rosdakarya. (1990). Psikologi Pendidikan. Bandung. Remaja Rosdakarya

Numan Somantri. (2001). Mengagas Pembaharuan Pendidikan IPS. Bandung: Remaja

Rosdakarya, Oemar Hamalik. (1992). Psikologi Belajar \& Mengajar. Bandung: Sinar Baru

Sapriya. (2011). Pendidikan IPS. Bandung. Remaja Rosdakarya

Sardiman. (1996). Interaksi Belajar Mengajar. Jakarta: Raja Grafindo Persada

Savage, Tom V \& Armstrong, David.C. (1996). Effective Teaching In Elementary Social Studies. New Jersey: Prentice Hall, Inc 
Simangunsong dan Zainal Abidin. (1987). Metodologi IIS (IPS) untuk SPG-SGOKPG dan Guru SD (1). Jakarta: CV Akademika Pressindo.

Slameto.(2003). Belajar dan Faktor-Faktor yang Mempengaruhinya. Jakarta: Rineka Cipta.

Slavin, Robert. (2010). Cooperative Learning. Bandung. Penerbit Nusa Media.

Sugiyono. (2012). Metode Penelitian Kombinasi (Mixed Methods). Bandung: Alfabeta.

Sumadi Suryabrata. (1990). Psikologi Pendidikan. Jakarta: PT Rajawali

Supardi.(2011). Dasar-Dasar Ilmu Sosial. Yogyakarta: Ombak
Suyatno. (2009). Menjelajah Pembelajaran Inovatif. Sidoarjo: Massmedia Buana Pustaka

Syaiful Sagala. (2009). Konsep dan Makna Pembelajaran untuk Membantu Memecahkan Problematika Belajar dan Mengajar. Bandung: Alfabeta

The Liang Gie. (1981). Cara Belajar yang Efisien. Yogyakarta: Gadjah Mada University Press

Trianto. (2010). Model Pembelajaran Terpadu. Jakarta: Bumi Aksara

Wina Sanjaya. (2005). Pembelajaran Dalam Implementasi Kurikulum Berbasis Kompetensi. Jakarta: Kencana

Zainal Aqib. (2009). Penelitian Tindakan Kelas. Bandung: Yrama Widya 